IMAGES IN...

\title{
Cardio-vocal syndrome
}

\section{Mehrnaz Asadi Gharabaghi, ${ }^{1}$ Mehrnoush Asadi Gharabaghi ${ }^{2}$}

${ }^{1}$ Department of Pulmonary Medicine, Tehran University of Medical Sciences, Tehran, Iran ${ }^{2}$ Department of Pharmacy, Maharashtra Institute of Pharmacy, Pune, Maharashtra, India

Correspondence to Dr Mehrnaz Asadi Gharabaghi, asadi_m@tums.ac.ir

\section{DESCRIPTION}

An 80-year-old man presented with a 3-monthhistory of hoarseness that developed gradually and remained with the same intensity afterwards.

He had neither a history of constitutional symptoms nor cardiorespiratory complaint. He worked as a farmer for 40 years and never smoked. He was taking atenelolol $100 \mathrm{mg}$ daily for hypertension.

He was initially referred to the otolaryngologist. On direct laryngoscopy, the movement of arytenoid cartilage and true vocal cord on the left side was impaired and no discrete mucosal lesion was seen $\mathrm{He}$ was referred to the pulmonology clinic to undergo fiberoptic bronchoscopy as there was ground glass opacity over the lateral segment of the right middle lobe and suspicious lymph adenopathy in the aorto-pulmonary window.

He was hypertensive with right arm blood pressure of $170 / 110 \mathrm{~mm} \mathrm{Hg}$. Otherwise, the rest of the examination was normal. Bronchoscopic examination was deterred as thrombosed dissection of the aortic arch was the most probable diagnosis.
A

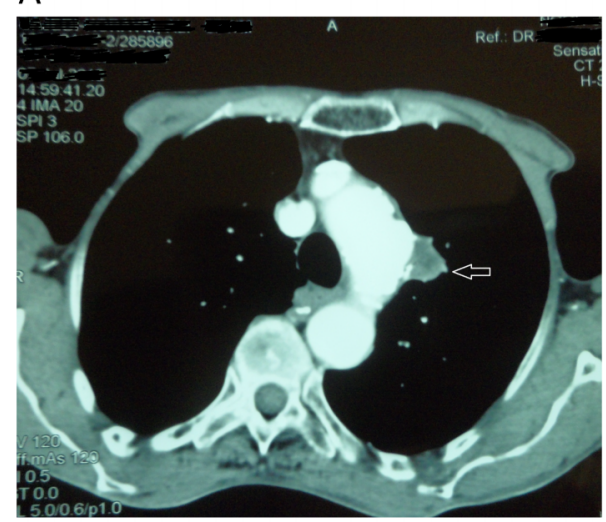

C

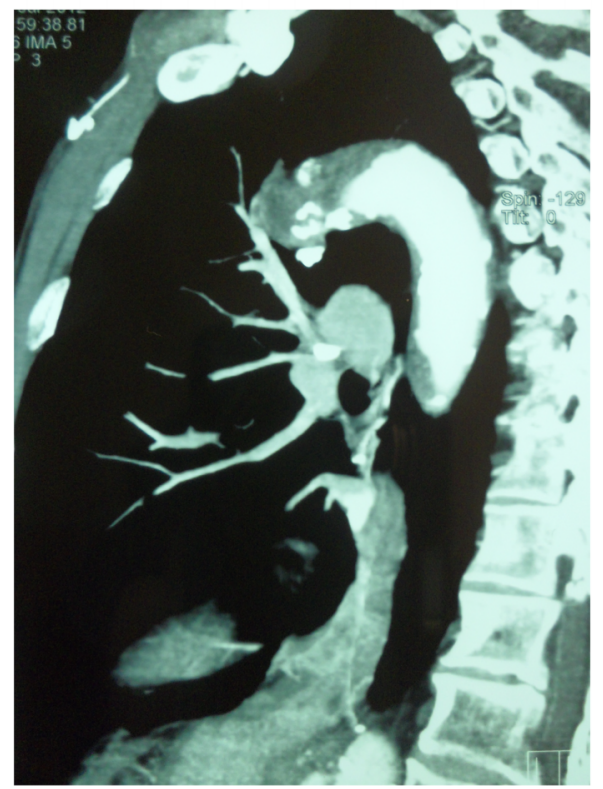

B

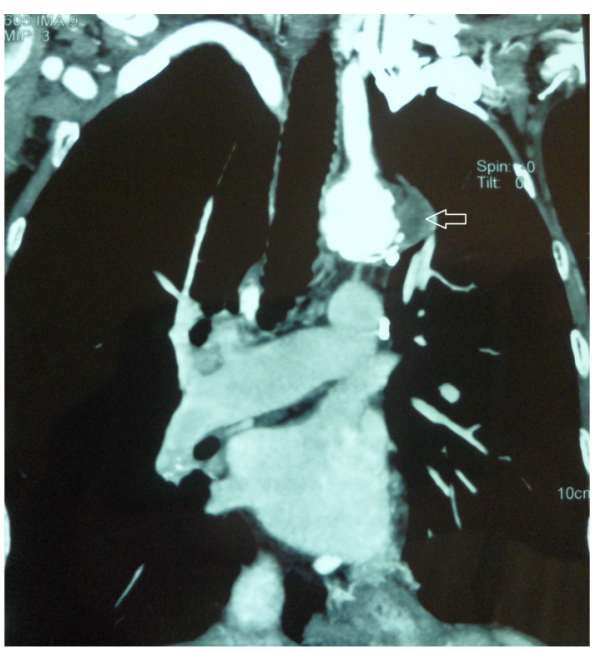

$\mathrm{D}$

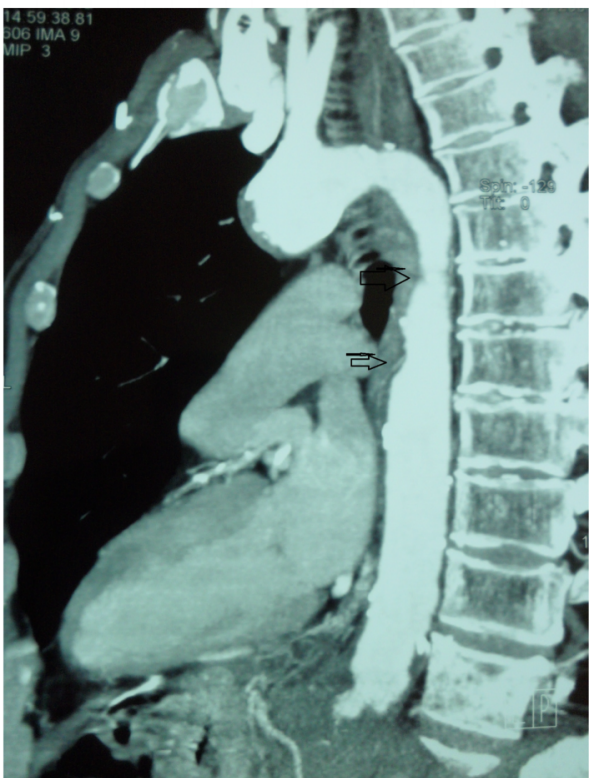

To cite: Asadi
Gharabaghi $M$, Asadi Gharabaghi M. BMJ Case Reports Published online: 2 January 2013 doi:10.1136/ bcr-2012-007633
Figure 1 (A-D) Axial, coronal and sagittal sections of thoracic aorta angiogram show aortic atherosclerosis and mural thrombosis in dissected aortic arch extending to the descending aorta. 
Therefore, he underwent angio-CT scan of the thoracic and abdominal aorta that showed mural thrombosis in the aortic arch extending to the descending aorta and consequent luminal irregularity and narrowing. There was also aneurysmal dilatation of the aorta from diaphragmatic hiatus to the origin of coeliac artery. The rest of the abdominal aorta was unaffected (figure $1 \mathrm{~A}-\mathrm{D})$. He refused to undergo further intervention and preferred to be followed up as an outpatient.

Cardiovocal syndrome is characterised by left recurrent laryngeal nerve (LRLN) palsy due to a cardiovascular disease. A variety of cardiac diseases can cause LRLN palsy by compressing or stretching effects. For instance, the nerve may be entrapped between the left pulmonary artery and dissected aortic arch or may be injured by a slowly expanding aortic arch aneurysm. ${ }^{1} 2$ The syndrome must be considered in differential diagnosis of hoarseness.

\section{Learning points}

- Thrombosed aortic arch dissection must be considered in differential diagnosis of aorto-pulmonary window lymph adenopathy.

- Cardiovocal syndrome must be considered in evaluation of patients with hoarseness and risk factors of cardiovascular disease.

\section{Competing interests None.}

Patient consent Obtained.

Provenance and peer review Not commissioned; externally peer reviewed.

\section{REFERENCES}

1 Subramaniam V, Herle A, Mohammed N, et al. Ortner's syndrome: case series and literature review. Braz J Otorhinolaryngol 2011;77:559-62.

2 Kishan CV, Wongpraparut N, Adeleke K, et al. Ortner's syndrome in association with mitral valve prolapse. Clin Cardiol 200023:295-7.

Copyright 2013 BMJ Publishing Group. All rights reserved. For permission to reuse any of this content visit http://group.bmj.com/group/rights-licensing/permissions.

BMJ Case Report Fellows may re-use this article for personal use and teaching without any further permission.

Become a Fellow of BMJ Case Reports today and you can:

- Submit as many cases as you like

- Enjoy fast sympathetic peer review and rapid publication of accepted articles

- Access all the published articles

- Re-use any of the published material for personal use and teaching without further permission

For information on Institutional Fellowships contact consortiasales@bmjgroup.com

Visit casereports.bmj.com for more articles like this and to become a Fellow 